7. Лессінг Г. Лаокоон / Г. Лессінг; пер. з англ. Є. Попович. - К. : Мистецтво, 1968. - 290 с.

8. Мусієнко О. С. Кінематограф Юрія Іллєнка: всі барви світу. Культура і життя. 2006. № 37. С. 2.

9. Мусієнко О. С. Телеекранізація. Яка вона? Культура і життя. 1976. 17 жовтня. С. 4.

10. Погрібна Л. 3. Твори М. Коцюбинського на екрані. Київ : Наукова думка, 1971. 157 с.

11. Сергеев Е. Перевод с оригинала: Телеэкранизация русской литературной классики. Москва: Искусство, 1980. 200 с.

12. Стех М-Р. Фільм "Лісова пісня. Мавка" - неповторна творча візія Юрія Іллєнка // електрон. вид. Zik.ua. 05.03.2018. URI: https://www.zik.ua/news/2018/03/05/marko_r_steh_film_lisova_pisnya_mavka_svoierid a_nepovtorna_tvorcha_1278723 (дата звернення: 10.08.2019).

13. Тынянов Ю. Поэтика. История литературы. Кино. Москва: Наука, 1977. 575 с.

\title{
References
}

1. Babishkin, O.K. (1966). Ukrainian Literature on Screen: a Literary Critical Essay. Kyiv : Radjansjkyj pysjmennyk [in Ukrainian].

2. Briukhovetska, L.I. (2006). Directed by Yuri llenka. Kino-Teatr, 2, 49-55 [in Ukrainian].

3. Buryak, B.S. (1967). By the laws of beauty. Kyiv : Dnipro [in Ukrainian].

4. Buryak, B.S. (1974). Progress and the world of the beautiful: Literary-critical articles. Kyiv: Radjansjkyj pysjmennyk [in Ukrainian].

5. Vartanov, A.S. (1961). Images of literature in graphics and cinema. Moscow: Akad. Nauk SSSR. Institut istorii iskusstv [in Russian].

Russian].

6. Demin, V.P. (1977). Position of a debutant, Cinema Panorama. (issue 2), (pp. 60-81). Moscow : Iskusstvo [in

7. Lessing, G. (2010). Laocoon. (E. Popovych, Trans). Kyiv: Mystectvo [in Ukrainian].

Ukrainian]

8. Musienko, O.S. (2006). Cinema of Yuri llenka: all the colors of the world. Kul'tura i zhyttja, 37, 2 [in

9. Musienko, O.S. (1976). Television Version of the Book adaptation. What is She Like? Kul'tura i zhyttja, 17 October, 4 [in Ukrainian].

10. Pogrebna, L.Z. (1971).Works by M. Kotsyubynsky on the screen. Academy of Sciences of the Ukrainian SSR, Institute of Art Studies, Folklore and Ethnography named after M.T. Rylsky. A. A. Romitsyn (Ed.). Kyiv : Naukova dumka [in Ukrainian].

11. Sergeev, E. (1980). Translation from the original: Television Version of the Book of Russian literary classics. Moscow : Iskusstvo [in Russian].

12. Stech, M-R. (2018). The film "Forest Song. Mavka" - unique creative art by Yuriya Illnka. Zik.ua, March, $3^{\text {rd }}$. Retrieved from https://www.zik.ua/news/2018/03/05/marko_r_steh_film_lisova_pisnya_mavka [in Ukrainian].

13. Tynyanov, Yu.N. (1977). Poetics. History of literature. Movie. Moscow : Nauka [in Russian].

Стаття надійшла до редакції 17.10.2019 р. Прийнято до публікації 20.11.2019 p.

УДК 7.03’06-044.247(=161.2): 784.092(100)

Дружинець Маріанна Ігорівна
викладач кафредри естрадного співу
Київської муніципальної академії
естрадного та циркового мистецтв,
здобувач Національної академії керівних
кадрів культури і мистецтв
ORCID 0000-0003-2843-8138
marianna.druzhinec@gmail.com

\section{МІЖНАРОДНИЙ ПІСЕННИЙ КОНКУРС ЄВРОБАЧЕННЯ ЯК ВАЖЛИВИЙ ЕТАП ІНТЕГРАЦІЇ УКРАЇНСЬКОЇ КУЛЬТУРИ}

\begin{abstract}
Мета статті - розглянути основні тенденції і перспективи розвитку пісенного конкурсу Євробачення в медіа-просторі України; розкрити історію та специфіку конкурсу, історію тріумфів, правила участі та можливості проекту, специфіку та функціонування, показавши їх роль в європеїзації та євроінтеграції української культури. Методологія дослідження полягає в застосуванні компаративного, історико-логічного, аналітичного методів. Зазначений методологічний підхід дозволяє розкрити та піддати аналізу пісенний конкурс, що транслювався на українському каналі. Наукова новизна. Вперше у цій статті намагалися висвітлити специфіку та основні тенденції пісенного конкурсу Євробачення, розглянути його як шоу, як фактор європеїзації та євроінтеграції української культури. Проте недостатня розробленість в науці проблеми робить деякі положення дискусійними, розв'язання яких є важливим для сучасного культурного життя. Висновки. Конкурс Євробачення дає можливість нашим артистам нести свою творчість в Європу, у світ, тим самим інтегрувати українську культуру. Цей конкурс $є$ стимулом для українських артистів, які, перш ніж виходити на світовий ринок у конкурсі Євробачення, - європеїзують свою творчість, роблять якісний європейський продукт світового рівня, не втрачаючи при цьому кодовості української нації та культури. Міжнародний пісенний конкурс Євробачення - високий ступінь інтеграції України у світову культуру масового зразка.
\end{abstract}

(С) Дружинець М. І., 2020 
Ключові слова: міжнародний пісенний конкурс Євробачення. європеїзація, євроінтеграція.

Дружинец Марианна Игоревна, преподаватель кафедры эстрадного пения Киевской муниципальной академии эстрадного и циркового искусств, соискатель Национальной академии руководящих кадров культуры и искусств

Международный песенный конкурс Евровидение как важный этап интеграции украинской культу-

ры

Цель статьи - рассмотреть основные тенденции и перспективы развития песенного конкурса Евровидение в медиа-пространстве Украины; раскрыть историю и специфику конкурса, историю триумфов, правила участия и возможности проекта, специфику и функционирования, показав их роль в европеизации и евроинтеграции украинской культуры. Методология исследования заключается в применении сравнительного, историкологического, аналитического методов. Указанный методологический подход позволяет раскрыть и подвергнуть анализу песенный конкурс, который транслировался на украинском канале. Научная новизна. Впервые в этой статье пытались осветить специфику и основные тенденции песенного конкурса Евровидение, рассмотреть его как шоу, как фрактор европеизации и евроинтеграции украинской культуры. Однако недостаточная разработанность в науке проблемы делает некоторые положения дискуссионными, решение которых важно для современной культурной жизни. Выводы. Конкурс Евровидение дает возможность нашим артистам нести свое творчество в Европу, в мир, тем самым интегрировать украинскую культуру. Этот конкурс является стимулом для украинских артистов, которые, прежде чем выходить на мировой рынок в конкурсе Евровидение, - европеизируют свое творчество, делают качественный европейский продукт мирового уровня, не теряя при этом кодовости украинской нации и культуры. Международный песенный конкурс Евровидение - высокая степень интеграции Украины в мировую культуру массового образца.

Ключевые слова: международный песенный конкурс Евровидение. европеизация, евроинтеграция.

Druzhinets Marianna, lecturer of the pop music department of Kyiv Municipal Academy of Pop and Circus Arts, the candidate of the pop art department of National Academy of Management of Culture and Arts

International European song competition as an important stage of integration of Ukrainian culture

The purpose of the article is to consider the main tendencies and prospects of development of the Eurovision Song Contest in the media space of Ukraine; to reveal the history and specifics of the competition, the history of the triumphs, rules of participation and opportunities of the project, specifics, and functioning, to show their role in the Europeanization and European integration of Ukrainian culture. The methodology of the study applies comparative, historical and logical, analytical methods. This methodological approach allows us to open and analyze the song contest broadcast on the Ukrainian channel. Scientific novelty. The author in this article tries to highlight the specifics and main trends of the Eurovision Song Contest for the first time, to consider it as a show, as a factor of Europeanization and European integration of Ukrainian culture. However, the lack of sophistication in the science of this matter makes some propositions controversial, the resolution of which is important for contemporary cultural life. Conclusions. The appearance of the Eurovision Song Contest indicates a high degree of integration of Ukraine into the world culture of the mass specimen. Having received high starting ratings, such projects are certainly widely represented in the Ukrainian television space. The Eurovision contest enables our artists to bring their creativity to Europe, to the world, thus integrating Ukrainian culture. This competition is an incentive for Ukrainian artists who, before entering the world market in the Eurovision Song Contest, provide Europeanization of their creativity, making a high-quality European product of the world level, without losing the coding of the Ukrainian nation and culture. The Eurovision Song Contest has a high degree of integration of Ukraine into the world culture of the mass specimen.

Key words: International Eurovision Song Contest, Europeanization, European integration.

Яскравим явищем в культурному просторі України є пісенний конкурс Євробачення (англ. Eurovision Song Contest; фpp. Concours Eurovision de la chanson), у якому відбувається змагання учасників-конкурсантів різних країн, що демонструють свої здібності, уміння й обдарування.

Міжнародний пісенний популярний конкурс Євробачення та велика кількість шоу на екрані, прискіплива увага до них з боку журналістики, дані соціологічних опитувань про високий рейтинг подібних передач обумовлюють актуальність дослідження цього питання. Стан вивчення телешоу ще не можна назвати задовільним, не вистачає комплексних досліджень, у яких би простежувалися культурно-історичні прогресії, поглиблений культурологічний аналіз міжнародного пісенного конкурсу та його ролі у європеїзації творчості артистів, учасників та євроінтеграції культури України, хоча варто звернути увагу на низку цікавих досліджень соціологічного, психологічного, культурологічного, музикознавчого напрямів, у яких зроблено важливі узагальнення.

У процесі вивчення телешоу, конкурсів-шоу не можна оминути загальні дослідження шоу як феномена культури (І. Коротаєва, В. Стаметов), шоу-технологій та загальної шоуїзації суспільства (К. Акопян, Н.Дубовик, М. Макуіценко. А. Скрипка). Концепт телевізійного шоу вже розробляється сучасними вченими, зокрема $є$ праці про особливості історичного телешоу (А. Урушадзе, Т. Хлиніна) та реаліті-шоу (Є. Гуцал, А. Оборська, А. Савенко, С. Уразова, Т. Шоріна).

Дослідники обирають різні критерії для визначення поняття «шоу»: характерні ознаки будьякого видовища, комунікативну складову, сокультурну специфіку, онтологічні виміри. Такі підходи свідчать не лише про масштабність та багатофункціональність означеного феномена, а й про його глибоке проникнення в усі сфери життя суспільства. Це явище вчені називають шоуїзацією. Так, Н. Дубовик у праці «Шоутизація сучасної культури», доходить висновку, «шоу виходить за рамки телебачення та індустрії розваг, стаючи сучасною карнавалізованою фрормою культури, що дозволяє авто- 
ру говорити про явище «шоутизації» [2, 224]. А. Скрипка у розвідці «Шоу-технології як фрорма соціальної комунікації» наголошує, що шоу стає універсальною комунікативною практикою сучасного суспільства, елементи якої проникають в сфери суспільного життя $[8,8]$. Ю. Романенко подає своє тлумачення терміна «шоуїзація» у «Проективному філософському словнику», дослівний переклад «показуха». На думку автора, шоуїзація - це устан сучасної цивілізації, обумовлена тотальним розповсюдженням засобів масової інформації та комуніції, яка виражається у маніпуляції зором натовпу, постійному прагненні виставити будь-які факти, явища напоказ, задоволення гіпертрофованої психологічної потреби у видовищах [7, 7]. К. Акопян під терміном «шоуїзація» у праці «Шлягеризація, шоуїзація $і$ ексәібіціонізація в сучасній культурі» має на увазі відносно самостійний процес розповсюдження шоу як специфічного соціокультурного феномена $[1,5]$.

Євробачення - популярний конкурс-шоу естрадної пісні серед країн-членів Європейського мовного союзу (EBU). Конкурс проходить щорічно, починаючи з 1956 року, і є одним з найбільш популярних неспортивних заходів у світі. Україна стала активним учасником конкурсу з 2003 р. Менеджмент конкурсу з української сторони здійснює Національна телекомпанія України, загальну координацію цього міжнародного конкурсу здійснює Європейська Мовна Спілка [6].

Ідея створення щорічного конкурсу Євробачення народилася в 1950 році. Це був період після Другої світової війни, а головною метою стало об'єднання артистів з усіх країн, які входили до Європейської спілки та транслювання їх виступів у рамках одного грандіозного концерту. Прообразом став італійський музичний фрестиваль «Санремо» 1951 року. Перший європейський пісенний конкурс відбувся 24 травня 1956 року під назвою «Eurovision Grand Prix» в місті Луґано (Швейцарія). У ньому взяли участь лише 7 країн, а кожен учасник виконував 2 пісні. Вже наступного року для учасників ввели обмеження на виконання тільки 1 композиції. Згодом назву було змінено на «Concours Eurovision de la chanson». Євробачення транслювалося за підтримки Європейської мовної спілки (ЄMC), яка, окрім пісенного конкурсу, транслювала різноманітні програми новин, спорту та висвітлювала спеціальні події. Однак саме Євробачення і досі є найпопулярнішою програмою ЄМС. Від 2000 року Євробачення має одну особливість - «Правило Великої п'ятірки». Велика п'ятірка - це країни, які спонсують конкурс, а тому одразу потрапляють до фріналу. Цими країнами є Франція, Німеччина, Великобританія, Іспанія та Італія. До 2004 року формат проведення шоу передбачав лише фінал, тобто проводився 1 день. Але, оскільки кількість охочих приєднатися до музичного свята щороку збільшувалась, виникла потреба у півфіналі. Формат проведення Євробачення у 2 півфінали та фрінал існує з 2008 року [5].

Обмежень щодо громадянства виконавців немає, однак щоб взяти участь у конкурсі учаснику повинно виповнитись 16 років. Від кожної країни в конкурсі бере участь один представник (соліст або група не більше 6 учасників), який виконує пісню тривалістю не більше трьох хвилин. Після виступу всіх учасників найбільш популярна пісня визначається шляхом телеголосування, у якому беруть участь усі країни, які виступали у фріналі та півфіналі, а також голосуванням членів журі [5].

Україна є єдиною європейською країною на Євробаченні, яка завжди успішно проходила передфінальні відбори (коли їх треба було проходити) і завжди виступала у фіналі в роки своєї участі в конкурсі. Україна дебютувала на Пісенному конкурсі Євробачення 2003 року. Ії̈ представив співак Олександр Пономарьов із піснею «Hasta la Vista», де посів 14 сходинку. У 2004 році співачка Руслана з піснею «Wild Dances» здобуває перемогу й право на проведення ювілейного 50-го Пісенного міжнародного конкурусу Євробачення в Україні. Європу підкорив номер української конкурсантки: справжнє шоу склалося з шаленого ритму, в основі якого відчувався фоольклорний наспів запальної пісні виконавиці, її «диких танців» разом із хореографічним колективом «Життя», та виразні сценічні костюми. На Пісенному конкурсі Євробачення 2005 року Україну представив гурт «ґринджоли» 3 піснею «Разом нас багато», де посів 19 сходинку. У 2006 році Тіна Кароль з піснею «Show Me Your Love» посідає 7 місце. Визначним і виразним виступом України в Європі вважають номер Вєрки Сєрдючки (Андрія Данилка) у 2007 році. Саме цей виступ приніс Україні срібло. У 2008 році Україну на конкурсі представляла Ані Лорак з піснею «Shady Lady», співачка принесла нашій країні теж 2 місце; у 2009 році - Світлана Лобода з піснею «Ве my Valentine», артистка посіла 12 місце. У 2010 році нашій країні 10 місце привезла Alyosha з композицією «Sweet People», у 2011 році - 4 місце здобула Міка Ньютон з піснею «Angel». У 2012 році представляла нашу державу Гайтана і зайняла 15 місце. Злата Огневич з піснею «Gravity» у 2013 році знову повернула Україну на п'єдестал пошани. Номер, який представила українка, був видовищним: Ігор Вовковинський виніс Злату на руках і поставив на платформу-камінь, де вона перебувала під час всього виступу. За казкову пісню Україні віддали 214 балів - і це принесло у нашу скарбничку «бронзу». Марія Яремчук з піснею «Tick-Tосk» на Євробачення у 2014 році в Копенгагені влаштувала справжнє шоу і отримала 6 місце. У 2015 році Україна вперше за всю історію конкурсу, у зв'язку зі складною ситуацією в країні, не брала участь у конкурсі. У 2016 році Україну представляла співачка Джамала з піснею «1944», яка здобула перемогу, набравши 534 бали. Це друга перемога України на пісенному конкурсі Євробачення. У 2017 році на конкурсі Євробачення2017 Україну представив гурт «O.Torvald» з піснею «Time», яка зайняла 24 місце (це найгірший результат в історії участі України). На Євробаченні 2018 Україну представив співак Melovin, де отримав 17 місце [9]. У 2019 році перемогу на національному відборі отримала Maruv, та через політичні кон- 
фрлікти, які виникли під час фінального ефіру та в подальшому, Україна не брала участь в конкурсі. Історію участі подаємо в таблиці.

\begin{tabular}{|c|c|c|c|c|c|c|c|}
\hline Рік & Виконавець & Мова / Пісня & Переклад & Фінал & Бали & ПФ & Бали \\
\hline 2003 & $\begin{array}{l}\text { Олександр } \\
\text { Понома } \\
\text { рьов }\end{array}$ & $\begin{array}{l}\text { Англійська «Hasta la } \\
\text { Vista» }\end{array}$ & $\begin{array}{l}\text { «До побаче } \\
\text { ння» }\end{array}$ & 14 & 30 & $\begin{array}{l}\text { Без } \\
\text { півфіi } \\
\text { налів }\end{array}$ & \\
\hline 2004 & Руслана & $\begin{array}{l}\text { Українська «Wild } \\
\text { Dances» } \\
\text { англійська }\end{array}$ & «Дикі танці» & 1 & 280 & 2 & 256 \\
\hline 2005 & $\begin{array}{l}\text { «ऍринджо } \\
\text { ли» }\end{array}$ & $\begin{array}{l}\text { Українська «Ра } \\
\text { зом нас багато» }\end{array}$ & & 19 & 30 & $\begin{array}{l}\text { Орга } \\
\text { ні } \\
\text { затор }\end{array}$ & \\
\hline 2006 & Тіна Кароль & англійська & $\begin{array}{l}\text { «Покажи } \\
\text { мені своє } \\
\text { кохання» }\end{array}$ & 7 & 145 & & 146 \\
\hline 2007 & $\begin{array}{l}\text { Вєрка } \quad \text { Cep- } \\
\text { дючка }\end{array}$ & німецька, англійська & $\begin{array}{l}\text { Танець } \\
\text { «Лаша Тум- } \\
\text { бай» }\end{array}$ & 2 & 235 & $\begin{array}{l}\text { Торічни } \\
\text { й ТОП- } \\
10\end{array}$ & \\
\hline 2008 & Ані Лорак & $\begin{array}{l}\text { Англійська «Shady } \\
\text { Lady» }\end{array}$ & $\begin{array}{l}\text { «Загадкова } \\
\text { леді» }\end{array}$ & 2 & 230 & 1 & 152 \\
\hline 2009 & $\begin{array}{l}\text { Світлана Ло- } \\
\text { бода }\end{array}$ & англійська & $\begin{array}{l}\text { «Будь моїм } \\
\text { Валенти } \\
\text { ном» }\end{array}$ & 12 & 76 & 6 & 80 \\
\hline 2010 & Alyosha & англійська & $\begin{array}{l}\text { «Любі лю- } \\
\text { ди» }\end{array}$ & 10 & 108 & 77 & 7 \\
\hline 2011 & Міка Ньютон & англійська & «Янгол» & 4 & 159 & 6 & 81 \\
\hline 2012 & Гайтана & англійська & $\begin{array}{l}\text { «Будь моїм } \\
\text { гостем» }\end{array}$ & 15 & 65 & 8 & 64 \\
\hline 2013 & Злата Огнєвіч & англійська & $\begin{array}{l}\text { «Тяжі } \\
\text { ння» }\end{array}$ & 3 & 214 & 3 & 140 \\
\hline 2014 & Марія Яремчук & англійська & «Тік-Так» & 6 & 113 & 5 & 118 \\
\hline 2015 & $\begin{array}{ll}\text { Не } & \text { брала } \\
\text { участь } & \\
\end{array}$ & & & & & & \\
\hline 2016 & Джамала & $\begin{array}{l}\text { англійська, кримсь- } \\
\text { котатар } \\
\text { ська }\end{array}$ & «1944» & 1 & 534 & 2 & 287 \\
\hline 2017 & $\begin{array}{l}\text { «O.Tor } \\
\text { vald» }\end{array}$ & англійська & «Час» & 24 & 36 & $\begin{array}{l}\text { Орга } \\
\text { ні } \\
\text { затор }\end{array}$ & \\
\hline 2018 & Mélovin & $\begin{array}{l}\text { Англійська «Under } \\
\text { the Ladder» }\end{array}$ & $\begin{array}{l}\text { «Під драби } \\
\text { ною» }\end{array}$ & 17 & 130 & 6 & 179 \\
\hline 2019 & $\begin{array}{ll}\text { He } & \text { брала } \\
\text { участь }\end{array}$ & & & & & & \\
\hline
\end{tabular}

Національний відбір - музичний конкурс, організований телекомпанією НСТУ (з 2016 року спільно з СТБ), що визначає представника України на пісенному конкурсі Євробачення. У перший ж рік спільногго проведення з «СТБ» шоу встановило рекорд України за смс-голосуванням, отримавши 344 268 унікальних голосів, з яких 37,77\% підтримало Джамалу. НСТУ забезпечує онлайн-трансляцію для іноземців з англомовним коментатором. 2018 року всі прямі ефіри нацвідбору на Євробачення транслюються в прямому ефірі на телеканалах СТБ і UA:ПЕРШИЙ, а також в онлайні [3].

Правила проекту (2016-2019) включають попередній відбір, півфінал, фрінал. Для участі у національному відборі необхідно представити виключно авторську пісню, яка жодним чином не була оприлюднена до 1 вересня попереднього року. Участь у всеукраїнському попередньому відборі можна брати у два способи: направити заявку на участь за формою, наведеною на сайтах ПрАТ «ММЦ-СТБ» та НТКУ або прийти на відбір в одному з шести міст України (Запоріжжя, Харків, Одеса, Львів, Дніпро, Київ). Одного з фіналістів відбору визначають за результами онлайн-голосування. Особи, що бажають скористатися цією можливістю, повинні обрати відповідно опцію на сайті при поданні анкети, що зробить анкету та матеріали, вказані на сайті як обов'язкові, доступними для перегляду всіх відвідувачів сайту. Голосування можуть здійснювати тільки відвідувачі сайту, що знаходяться на території України. 
Півфінал складається з чотирьох або трьох турів і фрінального туру з оголошенням переможця. У кожному турі беруть участь від 7 до 12 учасників, таким чином, кожен 3 переможців 1-го етапу може брати участь в одному турі півфіналу. Після завершення виступу кожного учасника 2-го етапу відбору, члени журі мають право прокоментувати виступ, висловити свої побажання та надати поради. До наступного етапу відбору проходять учасники півфіналу, що визначаються журі та глядачами відбору спільно. Оголошення переможців півфріналу здійснюється в день проведення того чи іншого півфіналу. У результаті проведення півфріналів обираються від 7 до 12 переможців півфріналу, по 2-3 переможці кожного з турів півфіналу. Півфінал відбору транслюється у прямому ефрірі телеканалів «СТБ» та «UA:Перший».

До участі у фіналі допускаються лише переможці півфріналу. Єдиним переможцем фріналу, який представлятиме Україну на конкурсі Євробачення, визнається учасник фріналу, який визначається журі та глядачами відбору спільно за правилами, що будуть оголошені додатково у прямому ефірі фріналу відбору. Оголошення переможця здійснюється в прямому ефірі фіналу. Фінал відбору транслюється у прямому ефрірі телеканалів «СТБ» та «UA: Перший».

За 13 виступів на Євробаченні Україна здобула два «золота», два «срібла» та одну «бронзу». Після тріумфу Джамали Київ приймав головне пісенне шоу Європи, країну представив рок-гурт O.Torvald [3].

Національний відбір - можливість для молодих і незалежних артистів проявити себе і презентувати свою творчість великій аудиторії. Тому хотілося б, щоби кожен етап відбору давав глядачам змогу побачити і оцінити якість інновації; дізнатися трохи більше про музику, що народжується в незалежній Україні. Євробачення відкриває телеаудиторії, український музичний горизонт і його таланти.

Тільки побачивши і почувши артиста наживо, можна давати якесь оціночне судження i тим більше гарантії. Записані в студії пісні - це одне, а виступ живцем - зовсім інше. Смислове навантаження композиції та меседж, який музиканти відправляють зі сцени, безумовно важливі, але свої оцінки в кінцевому підсумку кожен отримає за музику і аранжування, за те, наскільки якісно зроблений музичний продукт і вміння триматися на сцені. Будь-які тренди працюють тільки тоді, коли є бездоганне виконання, оригінальність і прорив в звучанні.

Цікаві ті учасники «Євробачення», які схильні до самобутності і оригінальності. Євген Філатов, композитор, саунд-продюсер, засновник українського гурту The Maneken, саунд-продюсер гуртів ONUKA i The Elephants, член Нацвідбору пісенного конкурсу «Євробачення» зазначав: «Цікаво спостерігати у Нацвідборі за гуртом «ЦеЩо». I хоча в житті "тато" цього проекту Влад Троїцький - театральний режисер, я в повній мірі можу назвати його музичним продюсером. Створені ним колективи «ДахаБраха» і Dakh Daughters - суперсамобутні музиканти, які довели, що оригінальна українська музика може завоювати весь світ. Тому я дуже сподіваюся, що і «ЦеЩо» покажуть відмінний номер. Ще одні музиканти, які заслуговують на увагу - гурт Brunettes Shoot Blondes. Оригінальність, унікальність і та величезну роботу, яка була виконана, у них є великий шанс бути оціненими за заслугами. Важливо пам'ятати, «Євробачення» - це шоу» [10]. I шоу в цьому конкурсі, погодимося з композитором, саундпродюсером, відіграє не менш важливу роль, ніж музика.

Таким чином, поява пісенного конкурсу Євробачення, свідчить про високий ступінь інтеграції України у світову культуру масового зразка. Отримавши високі стартові рейтинги, такі проекти, безумовно, широко представлені в українському телевізійному просторі. Євробачення - це конкурс, який дає можливість нашим артистам нести свою творчість в Європу, у світ, тим самим інтегрувати (інтеграція - асиміляція різнорідних елементів культури в єдину культуру) українську культуру. Цей конкурс $€$ певним стимулом для українських артистів, які перш ніж виходити на світовий ринок у конкурсі Євробачення, - європеїзують (європеїзація - внутрішні зміни відповідно до західноєвропейських стандартів [4]) свою творчість, роблять дійсно якісний європейський продук світового рівня, не втрачаючи при цьому своєї авторської самобутності та кодовості української нації та культури.

\section{תimepamyрa}

1. Акопян К. Шлягеризация, шоуизация и эксгибиционизация в современной культуре. Горизонты культуры: от массовой до элитарной. Санкт-Петербург, 2008. С. 15-21.

2. Дубовик Наталия Шоутизация современной культуры. V МІСТ: Мистецтво, історія, сучасність, теорія,

2010. № 7. C. 224-233.

3. Євробачення національний відбір. URL : https://uk.wikipedia.org/wiki/ (дата звернення 12.09. 2019).

4. Європеїзація. Євроінтеграція. URL: https://uk.wikipedia.org/wiki (дата звернення 1.09.2019).

5. Історія виникнення пісенного конкурсу Євробачення. URL: https://konkursevrov.blogspot.com/ (дата звернення 12.08.2019).

6. Пісенний конкурс Євробачення. URL: https://uk.wikipedia.org/wiki/ (дата звернення 7.09.2019).

7. Романенко Юрий. Шоуизация. Проективный философский словарь: Новые термины и понятия. URL : http://ontoimago.spb.nl/article_139.html (дата звернення 12.09.2019).

8. Скрипка Анна. Шоу-технології як форма соціальної комунікації : авторефр. дис. на здобуття паук, ступеня канд. соціологічних наук : спец. 22.00.04. Харків, 2010.

9. Україна на пісенному конкурсі Євробачення. URL: https://uk.wikipedia.org/wiki (дата звернення 12.08.2019). 
10. Чому "Євробачення" - це в першу чергу шоу, і чого варто від нього очікувати. Інтерв ю Євгена Філатова. URL: https://vk.com/@eurovision_ua-chomu-vrobachennya-ce-v-pershu-chergu-shou-chogo-varto-vd-nо (дата звернення 18.09.2019).

\title{
References
}

1. Akopjan, K. (2008). Hit-anization, show-anization and exhibitionism in contemporary culture.Ghoryzontu kuljturu: ot massovoj do эlytarnoj. Sankt-Peterburgh. (pp. 15-21). Sankt-Peterburh [in Russian].

2. 2.Dubovyk, Natalyja. (2010). Show-anization of modern culture. V MIST: Mystectvo, istorija, suchasnistj, teorija, 7, 224-233 [in Ukrainian].

3. 3.Eurovision national selection. (data zvernennia 12.09. 2019). Retrieved from: https://uk.wikipedia.org/wiki/.

4. 4.Europeanization. European integration. (data zvernennia 1.09.2019). Retrieved from: https://uk.wikipedia.org/wiki.

5. 5. History of the Eurovision Song Contest. (data zvernennia 12.08.2019). Retrieved from: https://konkursevrov.blogspot.com/.

6. 6.Eurovision Song Contest. (data zvernennia 7.09.2019). Retrieved from: https://uk.wikipedia.org/wiki/.

7. 7.Romanenko Juryj. (data zvernennia 12.09.2019). Show-anization. Proektyvnbj fylosofskyj slovarj: Novbe termynы у ponjatyjaю. Retrieved from: http://ontoimago.spb.nl/article_139.html.

8. 8.Skrypka, Anna. (2010). Show-technology as a form of social communication. Extended abstract of candidate's thesis. Xarkiv [in Ukrainian].

9. 9.Ukraine at the Eurovision Song Contest. (data zvernennia 12.08.2019). Retrieved from: https://uk.wikipedia.org/wiki.

10. Why Eurovision is a show and what is to be expected from it. Interview with Yevgen Filatov. (data zvernennia 18.09.2019). Retrieved from: https://vk.com/@eurovision_ua-chomu-vrobachennya-ce-v-pershu-chergu-shou-chogovarto-vd-no.

Стаття надійшла до редакції 21.11.2019 p. Прийнято до публікації 17.12.2019 р.

УДК 792.82(477)

\author{
Лук'яненко Катерина Аркадіївна \\ аспірантка Київського національного \\ університету культури і мистецтв \\ ORCID 0000-0003-1490-4601 \\ katechoreography@gmail.com
}

\section{УКРАЇНСЬКИЙ БАЛЕТНИЙ ТЕАТР 1960-1970-х рр.: СЦЕНІЧНІ ПРАКТИКИ}

\begin{abstract}
Метою статті $є$ визначення тенденцій реформування балетного мистецтва в 1960-1970-ті рр. та охарактеризувати процеси оновлення у вітчизняному балетному театрі. Методологія дослідження базується на поєднанні історичних, філософських, естетичних, культурологічних та мистецтвознавчих аспектів сучасного наукового пізнання. Застосовано загальнонаукові та конкретно-наукові методи (аналітичний, культурологічний, проблемнохронологічний, типологічний, мистецтвознавчий та теоретичного узагальнення). Наукова новизна. Розглянуто художню концепцію українського балетного театру, як синтез видів мистецтва та ідеї створення художньо-цілісної постановки. У даному контексті акцентовано на процесі формування естетичних ідей балетного театру в Україні як феномену, розвиток та оновлення якого відбувалися під впливом нових суспільних, історичних, культурномистецьких реалій та використання зарубіжного хореографічного та сценічного досвіду. Виявлено тенденції реформування балетного театру в Україні 1960-1970-х рр.; простежено еволюціонування виражальних засобів хореографії протягом означеного періоду та проаналізовано їх вплив на мову та форму балетної вистави. Висновки. Еволюціонування нових засобів виразності балетного театру в Україні в 1960-1970-ті рр. значно посприяло розширенню та поглибленню образної сфери вітчизняного хореографічного мистецтва, що відобразилося передусім на домінуванні у виставах провідних балетмейстерів-постановників найтонших психологічних нюансів та відтінків, проникненні вглиб предмету, майстерному відображенні дійсності та філософських ідей. Українські балетмейстери-постановники змінюють власне, частково «заангажоване» ставлення до руху, позбавляючись у сміливих експериментальних постановках канонів та заданих форм, в творчих пошуках власного стилю та мови. Проте, не зважаючи на тяжіння постановників до абстрактності та мінімалізму, все ж у балетних виставах українських оперних театрів зберігається програмність та сценарна основа.

Ключові слова: балетний театр, хореографрічне мистецтво, зарубіжні сценічні практики, творчі експерименти, новаторські виражальні засоби. и искусств

Лукьяненко Екатерина Аркадьевна, аспирантка Киевского национального университета культуры

Украинский балетный театр 1960-1970-х гг .: сценические практики

Целью статьи является определение тенденций реформирования балетного искусства в 1960-1970-е гг. и характеристика процессов обновления в отечественном балетном театре. Методология исследования базируется на сочетании исторических, философских, эстетических, культурологических и искусствоведческих аспектов современного научного познания. Применены общенаучные и конкретно-научные методы (аналитический, куль-
\end{abstract}

(C) Лук'яненко К. А., 2020 